\title{
Description of Students Critical Thinking Ability in Temperature and Calor Material
}

\author{
Darmaji ${ }^{1}$, Dwi Agus Kurniawan ${ }^{2}$, Astalini ${ }^{3}$, Retno Wulan Dari ${ }^{4}$ \\ Universitas Negeri Jambi, Indonesia ${ }^{1,2,3,4}$ \\ darmaji@unja.ac.id ${ }^{1}$, dwiagus.k@unja.ac.id ${ }^{2}$, astalinizakir@unja.ac.id ${ }^{3}$, \\ wulan21789@gmail.com ${ }^{4}$
}

Received: August $16^{\text {th }}, 2020$. Revised: October $19^{\text {th }}, 2020$. Accepted: October $21^{\text {th }}, 2020$

\section{Keywords :}

Critical Thinking Ability;

Physics Learning; Temperature and Heat Material

\begin{abstract}
The purpose of this study was to describe the critical thinking skills of students of SMAN 8 Muaro Jambi in physics learning material temperature and heat. The approach used in this study is a mixed-methods approach with a sequential explanatory design that combines sequential quantitative and qualitative research methods. The sample used in this study was 96 students of SMAN 8 Muaro Jambi. Data collection techniques using tests and interviews. The results showed that for the mastery of critical thinking skills as a whole on the material, the temperature and heat of the students were at a non-critical level with a percentage of $40.5 \%$. Based on the results of the study, it was found that students of SMAN 8 Muaro Jambi were in the non-critical category. The low ability of students to think critically is because students are not used to being presented with active learning that maximizes their thinking potential. By doing this research, the teacher can improve students' critical thinking skills in learning physics, especially temperature and heat material.
\end{abstract}

\section{INTRODUCTION}

Education is very important. Education is the activity of every human being to get a better quality of life [1]. To realize the expected educational goals, educators should be able to develop reasoning, the ability to think, and the self-concept of students to create meaningful learning for students. Classroom learning needs to be designed to involve students in active learning [2]. One of the efforts in the field of education to produce quality human resources is to form a culture of critical thinking in students in the learning process [3]. This strategy provides strength for students in terms of developing thinking skills.

Thinking skills developed through active learning activities are critical thinking skills. Thinking is the process that is created unconsciously in a person [4]. Critical thinking is a thinking activity that is carried out by operating the intellectual potential to analyze, make judgments, and make decisions appropriately and implement them correctly [5]. Critical thinkers can seek, understand, and evaluate relevant statements logically and rationally during the process of problem-solving or decision making [6]. 
Critical thinking is reflective thinking in depth in decision making and problem-solving to analyze situations, evaluate arguments, and draw appropriate conclusions [7]. Critical thinking is a very important ability for every individual because almost all aspects of life require critical thinking skills [8]. Think the critically important and should be owned by every individual to resolve the problems of life that is more complex in the current era of globalization [9]. Therefore students must be able to think critically per the demands of today's education.

The application of critical thinking skills in learning is very important, this is in line with the opinion the ability to think critically is a learning method or a good way that we must instill in the physics learning process [10]. learn racing physics in understanding the concepts of high requirements [11]. Physics is a branch of science that has uniqueness and characteristics [12]. Physics is seen as a process and a product, so the learning strategies or methods used must be effective and efficient [13]. Physics has become one of the subjects related to the scientific concept [14]. Physics plays an important role in explaining the various phenomena occurring in the universe [1]. Physics is the science that studies existing events, both those that can be observed directly or indirectly [15]. Thus students are required to follow and master the physics material being taught because physics plays an important role in developing critical thinking skills.

We can see the development of students' critical thinking skills in physics learning from their learning outcomes. The results of previous research indicate that critical thinking in learning physics can improve student achievement [16]. critical thinking skills affect student learning outcomes. Student which can think critically high, the results of their study will also be high [17]. The higher the level of critical thinking of students, the greater the significant functional relationship to physics learning outcomes [18]. Learning physics is one of the lessons that can improve students' critical thinking skills. The student will feel the importance of learning through the process of applying competence in everyday life, and they will be aware of what material they are learning [19].

Physics materials related to everyday life are temperature and heat [20]. In everyday life, the temperature is a measure of the heat or coldness of a substance or object [21]. Many household appliances are made using the principles of heat transfer [15]. For example the event of boiling water after heating on the stove [22]. At the material's hoot and calorific students demonstrate the ability of critical, students more familiar with the concept of examples for the students' daily lives often experience events and see an example of the temperature and heat [23]. So temperature and heat can develop critical thinking skills of students.

The purpose of implementing the 2013 curriculum is to develop critical thinking skills. Because currently, in Indonesia, the ability to think critically is a requirement for the 2013 curriculum [24]. Therefore, the 2013 curriculum should focus on building knowledge and encourage students to produce information that has value or meaning for them to develop new skills [25]. The 2013 curriculum requires a student-centered learning design so that teachers must know the nature of students, and know the right way or approach in tying the abilities that are goals in education today [26].

The selection of temperature and heat material in this study was based on the number of students still having difficulty learning temperature and heat materials. Based on the test results, students have difficulty understanding the temperature and heat material presented in graphs and pictures, difficulty understanding concepts, difficulties which relate to calculating numbers or using formulas, and the difficulty of making conclusions based on the analysis [27]. Physics lessons on temperature and heat material based on previous years' experience, the score of learning outcomes from daily tests/block tests is very low, ranging from 60\% to $70 \%$ under KKM (Minimal Completeness criteria) which is already set. That means only about $30 \%$ to $40 \%$ have been completed [28]. So from previous research, researchers will research to see students' critical thinking skills, whether at a low or high level. The novelty of the research carried out by researchers, namely, in this study the researcher will look at students 'critical thinking skills which lead to the demands of the 2013 curriculum. By conducting this research the teacher can improve students' critical thinking skills in learning physics, especially temperature and heat material. 
Based on this explanation, the application of critical thinking skills in learning is very relevant to the 2013 curriculum. Schools that have implemented the 2013 curriculum are considered to have accustomed students to critical thinking. Based on the description above, the researcher will analyze students' critical thinking skills in learning Physics at SMAN 8 Muaro Jambi. The purpose of this study was to describe the critical thinking skills of students of SMAN 8 Muaro Jambi in physics learning material temperature and heat.

\section{METHOD}

The approach used in this research is a mixed-methods approach with a sequential explanatory design that combines sequential quantitative and qualitative research methods, in which the first stage uses quantitative methods and the second stage uses qualitative methods. Quantitative methods were used to obtain data about students' critical thinking skills in physics lessons on temperature and heat material. Qualitative methods are used to obtain in-depth data about students' critical thinking skills in physics subject matter temperature and heat. The quantitative research design used is descriptive quantitative which intends to describe or explain an event or an incident that occurs at present in the form of meaningful data. The qualitative research design used is descriptive qualitative which aims to describe and analyze the characteristics of students' critical thinking abilities.

The sample used in this study was students of SMAN 8 Muaro Jambi, totaling 96 students of class XI MIPA 1 to XI MIPA 3 odd semester 2019/2020. Data collection techniques using tests and interviews. The test instrument used was the physical description of the temperature and heat material, while the interview instrument used a semi-structured interview guide to strengthen the data obtained by using the test technique. The collected data were then analyzed using qualitative descriptive analysis based on indicators of critical thinking skills. Indicators of critical thinking ability used in this study are basic classification, the basis for decision making or support, inference, and advanced classification. The scores of the students' work were then processed. The steps for processing the score data were: (1) determining the lowest score; (2) determine the highest score; (3) find the median; then (4) divides the range of values into four categories, namely very high, high, low and very low. The descriptive statistics used in this study are the maximum value, minimum value, mean, and median [29].

\section{RESULTS AND DISCUSSIONS}

In this study, researchers looked at the critical thinking skills of Muaro Jambi Senior High School students using four indicators including basic classification, the basis for decision making, interference, and advanced classification. For data on basic classification, ability indicators can be seen in the table.

Table 1. Description of the Basic Classification Capabilities of Temperature and Heat Material

\begin{tabular}{cccccccc}
\hline Indicator & Interval & Category & \% & Mean & Median & Min & Max \\
\hline & $0.0-3.0$ & Very Uncritical & 10.2 & & & & \\
Basic & $3.1-6.0$ & Uncritical & 53.1 & & & & \\
Classification & $6.1-9.0$ & Critical & 32.7 & 2.3061 & 2 & 1 & 4 \\
& $9.1-12$ & Very Critical & 4.1 & & & & \\
& Total & & 100 & & & & \\
\hline
\end{tabular}

Table 1 shows that for indicators of the basic classification abilities of temperature and heat material is included in the uncritical category with a percentage of $53.1 \%$. 
Table 2. Description of Abilities in Decision Making

\begin{tabular}{cccccccc}
\hline Indicator & Interval & Category & \% & Mean & Median & Min & Max \\
\hline & $0.0-2.0$ & Very Uncritical & 32.3 & & & & \\
Basic decision & $2.1-4.0$ & Uncritical & 54.2 & & & & \\
making & $4.0-6.0$ & Critical & 13.5 & 1,8125 & 2 & 1 & 3 \\
& $6.1-8.0$ & Very Critical & 0 & & & & \\
& Total & & 100 & & & & \\
\hline
\end{tabular}

Table 2 shows that the indicator for decision-making ability of material temperature and heat is included in the uncritical category with a percentage of $54 \%$.

Table 3. Description of Interference Capabilities

\begin{tabular}{cccccccc}
\hline Indicator & Interval & Category & \% & Mean & Median & Min & Max \\
\hline & $0.0-3.0$ & Very Uncritical & 30.2 & & & & \\
& $3.1-6.0$ & Uncritical & 55.2 & & & & \\
Interference & $6.1-9.0$ & Critical & 13.5 & 1.8542 & 2 & 1 & 4 \\
& $9.1-12$ & Very Critical & 1.0 & & & & \\
& Total & & 100 & & & & \\
\hline
\end{tabular}

Table 3 shows that for indicators of interference material temperature and heat are included in the critical category with a percentage of $55.2 \%$.

Table 4. Description of Advanced Classification Capabilities

\begin{tabular}{cccccccc}
\hline Indicator & Interval & Category & \% & Mean & Median & Min & Max \\
\hline & $0.0-1.0$ & Very Uncritical & 67.7 & & & & \\
Advanced & $1.1-2.0$ & Uncritical & 17.7 & & & & \\
Classification & $2.1-3.0$ & Critical & 13.5 & 1.4792 & 1 & 1 & 4 \\
& $3.1-4.0$ & Very Critical & 1.0 & & & & \\
& Total & & 100 & & & & \\
\hline
\end{tabular}

Table 4 shows that for indicators of advanced classification capabilities, temperature and heat material is included in the very uncritical category with a percentage of $67.7 \%$.

Table 5. Description of Strategy and Tactic Abilities

\begin{tabular}{cccccccc}
\hline Indicator & Interval & Category & \% & Mean & Median & Min & Max \\
\hline \multirow{5}{*}{ Strategy and } & $0.0-1.0$ & Very Uncritical & 51 & & & & \\
tactics & $1.1-2.0$ & Uncritical & 15.6 & & & & \\
& $2.1-3.0$ & Critical & 28.1 & 1.875 & 1 & 1 & 4 \\
& $3.1-4.0$ & Very critical & 5.2 & & & & \\
& Total & & 100 & & & & \\
\hline
\end{tabular}

Table 5 shows that for the indicator of strategy and tactics the material temperature and heat are included in the category of very uncritical with a percentage of $51 \%$.

Table 6. Mastery of Students' Critical Thinking Ability on Temperature and Heat

\begin{tabular}{ccccccccc}
\hline Theory & Interval & Category & Mean & Median & Min & Max & \% & f \\
\hline \multirow{2}{*}{ Temperature } & $18.00-31.50$ & Very Uncritical & & & & & 37.5 & 36 \\
and Heat & $31.51-45.00$ & Not Critical & 45.45 & 46.00 & \multirow{2}{*}{18.00} & 72.00 & 40.5 & 39 \\
& $45.10-58.50$ & Critical & & & & & 10.4 & 10 \\
& $58.51-72.00$ & Very Critical & & & & & 11.5 & 11 \\
\hline
\end{tabular}

Table 6 shows that for the mastery of critical thinking skills as a whole on the material, the temperature 
and heat of students are at a non-critical level with a percentage of $40.5 \%$.

Critical thinking is included in higher-order thinking skills. This is because the ability to think is the highest cognitive competence that students need to master in learning [30]. Critical thinking defines learners who are "able to think" logically and deeply, able to search for data and evaluate data systematically as a result of the learning process [31]. Physics learning is a lesson that requires students to think critically. Students who can think High criticality will have high learning outcomes. These characteristics of physics are expected to be used to familiarize and develop students' basic thinking skills towards higher-order thinking skills. Students those with critical thinking have high learning outcomes [32]. Critical thinking skills (CTS) train students to investigate, analyze information, and reflect [33]. So critical thinking skills are very important to be developed by teachers so that creating critical students according to the demands of the 2013 curriculum.

The results of the study indicate that students of SMAN 8 Muaro Jambi do not have high critical thinking skills. This is because students do not give an optimal response to the problems posed by the teacher, students are not able to describe the conditions in the problem being discussed, students do not have a strong curiosity, students are not able to use spoken language in a varied and interesting way to hear and are not able to communicate fluently and enthusiastically [34].

The researcher also conducted interviews with two students to see the students' critical thinking skills. The researcher provides 5 questions that contain critical thinking skills on temperature and heat material. Following are the items and responses of the two students that the researcher has concluded as one.

1. Apart from getting material from the teacher, do you always look for additional physics material from books or other references? Explain!

Student respondents: No, because my friends and I tend to wait for the material that the teacher delivers without exploring more from various sources.

2. Do you think that the more difficult the problem is given, the more challenged you will be to find a solution? Explain!

Student respondent: No, because the questions are difficult if I don't understand the concept of the material, the enthusiasm for doing or finding out is getting smaller. I will be challenged to work on the problems given when I understand the concept of the material being taught.

3. Are you actively working on the assignment given by the teacher? Explain

Student respondent: No, because I lack understanding of concepts and I can't do assignments individually.

4. Do you always answer questions asked by teachers? Clear

Student response: Sometimes, because when I understand the question being asked I will answer the question with enthusiasm.

5. Do you often ask questions when you find it difficult to learn physics? Explain!

Student response: Sometimes, if I don't understand and the material I think is interesting to follow, I will be enthusiastic about receiving the lesson and I will be happy to ask questions when I don't understand the material.

From the results of the interview above, it can be concluded that students have low critical thinking skills. This is in line with the results of research that has been conducted by researchers using research instruments in the form of test questions that contain aspects of critical thinking skills. The results of the analysis of the ability to think students on material critical temperature and heat are known that the ability to think students' critical classified low.

So it is necessary to do better coaching to improve students' critical thinking skills. Besides, students also need to get used to solving questions at the C4-C6 level. If students are often trained in critical thinking activities, their critical thinking skills can develop optimally. If students are allowed to use higher-level thinking at each grade level, students will get used to distinguishing between truth and lies, 
appearance and reality, facts and opinions, knowledge [35]. One way to practice critical thinking skills is through the learning process.

Teachers must be able to create learning that trains students 'critical thinking skills, training students' critical thinking skills that are done well will increase student interest in learning and be confident in solving problems so that learning outcomes are also maximized. Physics learning is still dominated by teachers, learning tends to memorize rather than develop thinking power so that students are weak in conveying their ideas, weak in analyzing, depending on others rather than being responsible for their own choices [36]. The nature of each activity of learning undertaken should assist students who have critical thinking skills to solve problems. Someone who thinks critically will be able to answer the issues that are important to the well. So critical thinking is very important for students because of the ability to think critically students can improve learning outcomes of physics in school [37]. Students who have low learning outcomes, then these students find it difficult to obtain information, find and develop critical thinking skills.

\section{CONCLUSION AND SUGGESTION}

Based on the results of data analysis and discussion, it can be concluded that students of SMAN 8 Muaro Jambi class XI MIPA can think not critically, this means that the student's critical thinking ability is low. This is evidenced by the percentage shown by the data. The low ability of students to think critically is because students are not used to being presented with active learning that maximizes their thinking potential. The results of this study provide an overview of teachers and researchers about the condition of high school students' critical thinking skills. The teacher must be more creative in designing and developing learning tools to improve students' critical thinking skills so that they become a habit. Teachers must involve students in learning situations that can stimulate students' ability to think critically through various active learning models.

\section{REFERENCES}

[1] Maison, M., Darmaji, D., Astalini, A., Kurniawan, D. A., \& Indrawati, P. S. (2019). Science process skills and motivation. Humanities \& Social Sciences Reviews, 7(5): 48-56.

[2] Walfajri, R. U., \& Harjono, N. (2019). Peningkatan kemampuan berpikir kritis dan hasil belajar tematik muatan IPA melalui model problem based learning kelas 5 SD. Jurnal Basicedu, 3(1): 1620.

[3] Fujika, A., Anggereini, E., \& Budiarti, R. S. (2015). Analisis Kemampuan Berpikir Kritis Siswa SMA N 5 Kota Jambi Melalui Pembelajaran Berbasis Masalah Pada Konsep Pencemaran Lingkungan. Biodik, 1(1): 1-10.

[4] Fazriyah, N., Supriyati, Y., \& Rahayu, W. (2018). Watson-Glaser's Critical Thinking Skills. In 2nd International Conference on Statistics, Mathematics, Teaching, and Research (pp. 1-6).

[5] Zunanda, M., \& Sinulingga, K. (2015). Pengaruh Model Pembelajaran Berbasis Masalah dan Kemampuan Berpikir Kritis Terhadap Keterampilan Pemecahan Masalah Fisika Siswa SMK. Jurnal Pendidikan Fisika, 4(1): 63-70.

[6] Shaw, A., Liu, O. L., Gu, L., Kardonova, E., Chirikov, I., Li, G., ... \& Su, Q. (2020). Thinking critically about critical thinking: validating the Russian HEIghten ${ }^{\circledR}$ critical thinking assessment. Studies in Higher Education, 45(9): 1933-1948.

[7] Mason, M. (2007). Critical thinking and learning. Educational philosophy and theory, 39(4): 339349.

[8] Maison, M., Astalini, A., Kurniawan, D. A., \& Yuniyarsih, S. (2018). Student's Attitude Description Toward Physics On Secondary School. Edusains, 10(1): 160-167.

[9] Maison, M., Ernawati, D. W., Budiarti, R. S., Kurniawan, W., Ningsih, Y., Puspitasari, T. O., Jannah, N., \& Putra, D. S. (2019). Learning In Nature Science: Social Implications, Normality Of Scientist, Attitudes Towards Investigation Of Natural Science, And Interest Adds To Science 
Learning Time, International Journal of Scientific \& Technology Research, 8(12): 1478-1484.

[10] Syafitri, R., Asyhar, R., \& Asrial, A. (2016). Pengaruh Model Inquiry Training dan Berpikir Kritis Terhadap Kemampuan Berpikir Ilmiah Mahasiswa pada Mata Kuliah Kimia Dasar. Edu-Sains: Jurnal Pendidikan Matematika dan Ilmu Pengetahuan Alam, 5(1).

[11] Putri, A. R., Maison, M., \& Darmaji, D. (2018). Kerjasama Dan Kekompakan Siswa Dalam Pembelajaran Fisika Di Kelas XI MIPA SMA Negeri 3 Kota Jambi. EduFisika: Jurnal Pendidikan Fisika, 3(02): 32-40.

[12] Maison, M., Syahrial, S., Syamsurizal, S., \& Tanti, T. (2019). Learning Environment, Students' Beliefs, And Self-Regulation In Learning Physics: Structural Equation Modeling. Journal of Baltic Science Education, 18(3): 389-403.

[13] Astuti, S. P. (2015). Pengaruh kemampuan awal dan minat belajar terhadap prestasi belajar fisika. Formatif: Jurnal Ilmiah Pendidikan MIPA, 5(1): 68-75.

[14] Astalini, A., Kurniawan, D. A., Darmaji, D., Sholihah, L. R., \& Perdana, R. (2019). Characteristics Of Students' Attitude To Physics In Muaro Jambi High School. Humanities \& Social Sciences Reviews, 7(2): 91-99.

[15] Hadi, E., \& Yani, A. (2018). Identifikasi Miskonsepsi Materi Fisika Suhu Dan Kalor Menggunakan CRI (Certainty of Response Index) Pada Peserta Didik Kelas XI MIA SMA Negeri 8 Bulukumba. Jurnal Sains Dan Pendidikan Fisika (JSPF), 14: 44-54.

[16] Mulyono, Y. (2018). Critical Thinking Skills of Physics Education Students Through CTL-Based Fundamental Biology. In Science, Engineering, Education, and Development Studies (SEEDS): Conference Series (Vol. 2, No. 1).

[17] Komariyah, S., \& Laili, A. F. N. (2018). Pengaruh kemampuan berpikir kritis terhadap hasil belajar matematika. JP3M (Jurnal Penelitian Pendidikan dan Pengajaran Matematika), 4(2): 53-58.

[18] Husnah, M. (2017). Hubungan tingkat berpikir kritis terhadap hasil belajar fisika siswa dengan menerapkan model pembelajaran problem based learning. PASCAL (Journal of Physics and Science Learning), 1(2): 10-17.

[19] Abdullah, A. A., \& Suhartini, S. (2017). Meningkatkan Kemampuan Berpikir Kritis Melalui Pembelajaran Statistika Berbasis Pendidikan Politik Di Lingkungan Sekolah. Jurnal Gantang, 2(1): $1-9$.

[20] Maison, M., Safitri, I. C., \& Wardana, R. W. (2019). Identification of Misconception of High School Students on Temperature and Calor Topic Using Four-Tier Diagnostic Instrument. Edusains, 11(2): 195-202.

[21] Supu, I., Usman, B., Basri, S., \& Sunarmi, S. (2017). Pengaruh Suhu Terhadap Perpindahan Panas Pada Material Yang Berbeda. Dinamika, 7(1): 62-73.

[22] Lestari, M. Y., \& Diana, N. (2018). Keterampilan proses sains (KPS) pada pelaksanaan praktikum Fisika Dasar I. Indonesian Journal of Science and Mathematics Education, 1(1): 49-54.

[23] Sofiana, N., Dp, N. M., \& Nugroho, S. E. (2012). Pengembangan Evaluasi Peta Konsep Dalam Pembelajaran Inkuiri Pada Pokok Bahasan Kalor. Upej (Unnes Physics Education Journal), 1 (1).

[24] Wahyudi, R., Rukmini, D., \& Bharati, D. A. L. (2019). Developing Discovery Learning-Based Assessment Module to Stimulate Critical Thinking and Creativity of Students' Speaking Performance. English Education Journal, 9(2): 172-180.

[25] Alismail, H. A., \& McGuire, P. (2015). 21st century standards and curriculum: Current research and practice. Journal of Education and Practice, 6(6): 150-154.

[26] Yediarani, R. D., Maison, M., \& Syarkowi, A. (2019). Scientific reasoning abilities profil of junior high school students in Jambi. Indonesian Journal of Science and Education, 3(1): 21-25.

[27] Ma'rifah, E. Parno, P., \& Mufti, N. (2016). Identifikasi kesulitan siswa pada materi suhu dan kalor. Jurnal Pembelajaran Fisika, 4(5): 124-133.

[28] Pamungkas, S. (2018). Meningkatkan Motivasi dan Hasil Belajar Mata Pelajaran Fisika Materi Suhu dan Kalor Melalui Pembelajaran Kooperatif Tipe Jigsaw. PSEJ (Pancasakti Science Education Journal), 3(2): 83-90.

[29] Poerwanti, E. (2008). Asesmen Pembelajaran SD. Jakarta: Depdiknas.

[30] Surasa, N. N., Witjaksono, M., \& Utomo, S. H. (2017). Proses belajar siswa dalam meningkatkan kemampuan berpikir kritis mata pelajaran ekonomi SMA. Jurnal Pendidikan: Teori, Penelitian, dan Pengembangan, 2(1): 78-84. 
[31] Johan, H. (2013). Pengaruh SSCS problem solving untuk meningkatkan keterampilan berpikir kritis mahasiswa pada pembelajaran konsep listrik dinamis. Jurnal Pendidikan Matematika \& IPA, 4(1): 13-18.

[32] Winiasih, R., Ashadi, A., \& Mulyani, B. (2018). Kontribusi Kemampuan Berpikir Kritis dan Kemampuan Memori Terhadap Prestasi Belajar Ikatan Kimia pada Siswa Kelas X SMAN 2 Sukoharjo Tahun Ajaran 2016/2017. Jurnal Pendidikan Kimia, 7(1): 137-145.

[33] Wartono, W., Alfroni, Y. F., Batlolona, J. R., \& Mahapoonyanont, N. (2019). Inquiry-Scaffolding Learning Model: Its Effect on Critical Thinking Skills and Conceptual Understanding. Jurnal Ilmiah Pendidikan Fisika Al-Biruni, 8(2): 249-259.

[34] Rohim, F., \& Susanto, H. (2012). Penerapan model discovery terbimbing pada pembelajaran fisika untuk meningkatkan kemampuan berpikir kreatif. UPEJ Unnes Physics Education Journal, 1(1).

[35] Nuryanti, L., Zubaidah, S., \& Diantoro, M. (2018). Analisis kemampuan berpikir kritis siswa SMP. Jurnal Pendidikan: Teori, Penelitian, dan Pengembangan, 3(2): 155-158.

[36] Husein, S., Herayanti, L., \& Gunawan, G. (2017). Pengaruh penggunaan multimedia interaktif terhadap penguasaan konsep dan keterampilan berpikir kritis siswa pada materi suhu dan kalor. Jurnal Pendidikan Fisika dan Teknologi, 1(3): 221-225.

[37] Nugraha, M. G., Utari, S., Saepuzaman, D., Solihat, F. N., \& Kirana, K. H. (2019, November). Development of basic physics experiments based on science process skills (SPS) to enhance mastery concepts of physics pre-service teachers in Melde's law. In Journal of Physics: Conference Series (Vol. 1280, No. 5, p. 052075). IOP Publishing. 